\title{
MODAL SOSIAL DAN PRAKTIK GOTONG ROYONG PARA PENGRAJIN GULA KELAPA DI DESA KETANDA KABUPATEN BANYUMAS
}

\author{
Dodi Faedlulloh \\ Program Studi Ilmu Administrasi Publik Universitas 17 Agustus 1945 Jakarta \\ Email: dodifaedlulloh@gmail.com
}

\begin{abstract}
Palm sugar is an important commodity for Indonesia. In Banyumas regency, it plays an essential role too. Unfortunately, the palm sugar makers remain far from prosperity. There is an imbalanced social relation, the palms sugar makers are always in subordinate position towards middleman and big corporations above them. Given this condition, some palm sugar maker decided to organize themselves to have some cooperations in improving their quality of economc life. It also helps them to strengthen their bargaining position by establishing an organization called Argo MulyoJati. With its available social capital, certain value is being institutionalized in Katanda village, called GotongRoyong (mutual cooperation). Actually, It has existed inherently in the lifes of Indonesian people. Despite being a newly-born organization Argo MulyoJati is able to prove that collective work could enhance their bargaining position among the stakeholders in Katanda village. It is achieved with high level of social trust that has been growing as their social capital. This study explains how the role of social capital and the practice of mutual cooperation are conducted by members of Argo Mulyo Jati. The discussion is limited on the reformation of social capital as a power owned by palm maker, their aspect of trust as a part of social capital which supports the development of Argo MulyoJati Co-operative, and how is the institutionalization process of GotongRoyong value in the organization activities.
\end{abstract}

Key words: Palm Sugar, Mutual Cooperation, Social Capital

\section{PENDAHULUAN}

Gula kelapa adalah salah satu komoditas yang cukup penting di Indonesia. Bahkan penjualannya kini sampai menembus pasar dunia. Permintaan pasar dunia sudah mencapai 1.000 ton per bulannya (www.swa.co.id, 2016). Karena kadar gula yang rendah, gula kelapa, khususnya produk gula semut dinilai aman untuk dikonsumsi oleh orang yang terkena diabetes. Hal itulah yang menjadi nilai lebih dari produk gula kelapa dibanding gula lainnya.

Namun sayang manisnya rasa gula kelapa yang dihasilkan tidak semanis nasib para pengrajin gula kelapa. Masih banyak pengrajin yang masih jauh dari sejahtera. Hal- hal mendasar seperti keamanan kerja dan jaminan sosial tidak banyak didapatkan oleh para pengrajin. Kekuatan yang terbatas membuat mereka tidak bisa mengendalikan harga yang kerap dimonopoli oleh para tengkulak. Dengan modal yang minim membuat mereka juga terpaksa terjebak dalam lingkaran hutang kepada rentenir.

Kondisi memprihatinkan dari para pengrajin gula kelapa juga masih terjadi di Kabupaten Banyumas, salah satu daerah yang menjadi pusat pembuatan gula kelapa di Indonesia. Berdasarkan data yang disampaikan oleh Dinperindagkop Kabupaten Banyumas (2015), industri gula kelapa merupakan $74 \%$ dari total unit industri kecil menengah di Banyumas dengan menyerap 
tenaga kerja sampai 110.000 orang. Para pengrajin membuat gula dengan berbagai jenis seperti gula cetak, kristal atau sering dikenal dengan gula semut, krsital jahe, dan gula kelapa kristal kombinasi. Masih menurut informasi dari Dinperindagkop Kabupaten Banyumas pasar ekspor gula kelapa antara lain Amerika, Australia, Eropa, Jepang, Hongkong, Korea Selatan, Singapura, dan Timur Tengah.

Kabupaten Banyumas memiliki luas lahan pohon kelapa 17.814 hektare dengan luas lahan kelapa deres mencapai 4.798,41 hektare. Sedangkan dari sisi jumlah pohon kelapa yang dideres mencapai 460.980 pohon dengan produktivitas sampai 60.459 ton per tahunnya. Dengan potensi ini tentu menjadi sebuah ironi, bila para pelaku ekonominya, yaitu para pengrajin gula kelapa masih jauh dari sejahtera. Korporasi-korporasi besar dari ibu kota mengambil komoditas bahan baku bagi produk olahan seperti kecap. Sebagai bahan olahan, gula kelapa menjadi primadona bagi Kabupaten Banyumas. Kompetisi antara korporasi pun terjadi, namun seperti halnya yang terjadi pada produk pertanian lain, harga seringkali dipermainkan. Dalam relasi ini, pihak yang selalu dirugikan tiada lain para pengrajin gula kelapa yang hanya punya modal kekuatan kerja dan tubuhnya saja.

Ada relasi sosial yang tidak seimbang diantara para pemangku kepentingan dalam bidang gula kelapa ini. Para pengrajin selalu dalam posisi sub-ordinat dari para tengkulak, dan perusahaan besar yang ada di atasnya. Tidak banyak yang bisa dilakukan oleh para pengrajin, karena informasi, pengetahuan dan modal yang terbatas mencipatakan kondisi rasionalitas jinak yang dimanfaatkan untuk melakukan eksploitasi oleh pihak-pihak yang lebih kuat kepada para pengrajin. Dalam hal ini, para tengkulak secara langsung menciptakan hubungan kerja patron-client yang mengakibatkan para pengrajin kesulitan mendapat akses harga gula kelapa secara penuh (Jaetulloh, 2015). Hubungan ini sudah terjalin puluhan tahun lamanya.

Desa Ketanda merupakan salah satu desa di Kabupaten Banyumas yang mayoritas warganya berprofesi sebagai pengrajin gula kelapa. Profesi dimaknai sebagai pekerjaan utama, bukan pekerjaan sampingan. Karena di beberapa desa lain di Kabupaten Banyumas, menjadi pengrajin adalah kerja sampingan.

Hal menarik yang terjadi di Desa Ketanda dimulai awal tahun 2014 yang mana ada beberapa pengrajin yang melakukan inisiasi untuk memperbaiki kualitas hidup dengan cara membentuk kelompok pengrajin. Kondisi harga beli yang tidak stabil, kendala pemasaran, tidak adanya jaminan sosial merupakan permasalahan yang menjadi permasalahan setiap hari ditemui oleh para pengrajin. Latarbelakang inilah yang memberi inspirasi sebagian masyarakat untuk bergerak melakukan self-help dengan berorganisasi.

Pada dasarnya para pengrajin di Desa Ketanda sudah memiliki modal sosial yang baik. Dilihat dari rutinitas rembugan warga yang mereka lakukan. Ada arisan atau kegiatan-kegiatan gotong royong yang rutin berjalan. Namun modal sosial tersebut belum optimal sampai dikonversi menjadi modal finansial dan kekuatan lembaga. Misal, karena dalam arisan biasanya uang yang diperoleh tidak banyak karena hanya dilakukan untuk mengikat orang agar mau terlibat dalam 
berbagai kegiatan kelompok. Relasi keluarga juga merupakan bentuk modal sosial yang sebenarnya bisa menjadi daya dukung dalam memperoleh bantuan finansial akan tetapi biasanya orang merasa enggan untuk mendapatkan uang dengan meminjam pada saudaranya (Purwanto, 2013). Kekosongankarenagap modal sosial inilah yang kemudian coba diisi oleh kalangan pegiat koperasi dari Kopkun Institute, lembaga sub-otonom di bawah Koperasi Konsumen Kopkun yang concern dalam kajian dan pemberdayaan di bidang ekonomi, sosial dan koperasi yang berdomisil di Purwokerto. Lembaga ini melaksanakan pendampingan kepada para pengrajin di Desa Ketanda sampai pada akhirnya tanggal 25 April 2014 didirikan organisasi (pra-koperasi) di bawah payung nama Koperasi Argo Mulyo Jati. Melalui organisasi ini diharapkan terbangun ruang koordinasi segala potensi yang dimiliki pengrajin untuk menyelesaikan berbagai masalah yang sering mereka hadapi setiap hari.

Ada nilai yang kembali dicoba dilembagakan dalam kehidupan para pengrajin di Desa Ketanda, yaitu nilai gotong royong. Sebuah nilai yang sebenarnya sudah melekat dalam kehidupan masyarakat Indonesia. Gotong royong telah beruratberakar dan tersebar dalam kehidupan bermasyarakat di Indonesia dan menjadi pranata sosial yang paling penting dalam pembangunan(Collette, 1987)(Berutu, 2005).

Studi ini ditujukan sebagai produksi pengetahuan secara mendalam bagi peran modal sosial dan proses praktik gotong royong yang dilakukan oleh para pengrajin gula kelapa di Desa Ketanda yang mendirikan
Koperasi Argo Mulyo Jati sebagai upaya peningkatan kualitas hidup mereka. Pembahasan dibatasi pada penataan kembali modal sosial sebagai kekuatan yang dimiliki oleh para pengrajin, dan aspek kepercayaan sebagai bagian dari modal sosial yang mendukung pada pengembangan organisasi Koperasi Argo Mulyo Jati, serta bagaimana proses pelembagaan nilai gotong royong dalam aktivitas organisasi.

\section{METODE}

Studi ini dilakukan dengan menggunakan metode kualitatif. Metode kualitatif merupakan prosedur pengumpulan data yang menghasilkan data deskriptif berupa kata-kata tertulis atau lisan dari orangorang dan perilaku yang diamati(Moleong, 2004). Sedangkan untuk memilih informan peneliti menggunakan purposive sampling. Selain itu, untuk mempertajam analisis hasil dalam pembuatan model pengelolaan, peneliti juga menggunakan pendekatan studi kepustakaan dengan penelitian berbasis data sekunder.

Studi kepustakaan merupakan teknik pengumpulan data dengan mengadakan studi penelaahan terhadap buku-buku, literaturliteratur, catatan-catatan, laporan-laporan yang ada kaitannya dengan masalah yang hendak dipecahkan(Nazir, 2009). Studi pustaka memberi landasan teoritis untuk menjelaskan fenomena modal sosial serta pelembagaan gotong royong yang terjadi di Koperasi Argo Mulyo Jati, Desa Ketanda.

MODAL SOSIAL SEBAGAI KEKUATAN 
Modal sosial menjadi alternatif dari diskursus arus utama yang selalu mengedepankan modal ekonomi terlebih dahulu. Sebenanya tidak hanya dalam tataran diskursus, namun juga praxis. Dalam beberapa kajian akademik banyak temuan penting yang menjelaskan urgensi modal sosial selain modal ekonomi dalam kehidupan masyarakat.

Membicarakan modal sosial berarti mempelajari bagaimana masyarakat bekerjasama membangun suatu jaringan untuk mencapai tujuan bersama memperbaiki kualitas kehidupan. Dimensi utama pada kajian modal sosial adalah pola interaksi antar individu dalam kelompok dan antar kelompok dengan ruang perhatian pada jaringan sosial, norma, nilai dan kepercayaan antar sesama yang lahir dari sebuah kelompok. Seperti yang diungkapFukuyama (2002) modal sosial memiliki dimensi yang sangat luas menyangkut segala sesuatu yang membuat masyarakat bersekutu untuk mencapai tujuan bersama atas dasar kebersamaan, dan di dalamnya diikat oleh nilai-nilai dan norma-norma-norma yang tumbuh dan dipatuhi. Di sisi lain, Bourdieu (1986)menjelaskan modal sosial sebagai agregat sumberdaya aktual dan potensial yang dikaitkan dengan pemilikan jaringan hubungan perkenalan dan pengakuan yang terlembaga dan awet yang memberikan para setiap anggotanya dukungan modal yang dimiliki secara kolektif. Modal sosial yang dijelaskan Bourdieu diandaikan sebagai wahana bagi agen untuk mencapai tujuan instrumental. Oleh karenanya, jaringan sosial sebagai bagian dari modal sosial, menurut pandangan Bourdeu dibangun untuk mencapai keuntungan.

Konflik sosial adalah bagian dari realitas baik yang aktual maupun masih potensial. Oleh karena itu, Bourdieu juga menjelaskan ihwal penting tentang solidaritas kelompok sebagai bagian dari modal sosial. Solidaritas kelompok yang dimaksud merupakan solidaritas dari suatu kelompok sebagai bagian dari kelompok yang lebih besar, bukan sebaliknya(Bourdieu, 1986). Oleh karenanya modal sosial belum tentu berujung pada luaran aktivitas positif. Modal sosial juga bisa digunakan oleh semacam organisasiorganisasi teroris atau mafia dalam menjalankan tujuannya.

Modal sosial adalah hasil dari struktur sosial yang menunjuk pada segi organisasi sosial seperti kepercayaan, norma, dan jaringan yang melekat dalam kehidupan masyarakat dengan konteks latar belakang sosio ekonomi dan politiknya (Putnam, 1993). Dengan modal sosial yang kuat, maka akan terbangun organisasi sosial yang kuat pula.

Dalam konteks Indonesia, modal sosial seringkali termanifestasi ke dalam budaya gotong royong dan rembug warga. Tradisi tolong menolong maupun gotong royong telah lama menjadi ciri khas negeri ini(Widayani \& Rachman, 2013). Penekanan penting dari modal sosial adalah kebersamaan masyarakat untuk memperbaiki kualitas hidup secara bersama-sama. Hal ini yang senada dengan latar belakang didirikannya Koperasi Argo Mulyo Jati yang hendak memperbaiki nasib para anggotanya dengan jalan bergotong royong. Dalam konteks ini, tepatlah apa yang dijelaskan Burt (dalam Kusumastuti, 2015) yang menjelaskan modal 
sosial sebagai bentuk kemampuan masyarakat untuk melakukan asosiasi satu sama lain sehingga menjadi kekuatan yang sangat penting, tidak hanya pada aspek ekonomi tetapi juga pada ranah sosial. Dengan kata lain, modal sosial bisa menjadi modal yang sangat produktif untuk mencapai suatu tujuan (Sidik, 2015).

Manusia dalam memenuhi kebutuhan hidupnya tidak bisa berjalan sendiri. Manusia saling membutuhkan dan bekerjasama, oleh karenanya manusia selalu disebut mahluk sosial. Kerjasama yang terjalin mampu menjadi ikatan sosial (bounding social capital) antar anggota masyrakat, jembatan sosial (bridging social capital) antar anggota masyarakat, kelompok yang terbentuk juga mampu menjadi linking social capital di mana masyarakat mampu menjalin kerjasama dengan pihak pemerintah maupun sektor lainnya (Arianto \& Fitriana, 2013). Jejaring yang menghubungkan kerjasama tersebut tak lain adalah modal sosial. Modal sosial adalah kunci keberhasilan dari suatu organisasi sosial (Putnam, 2000). Kemudian, modal sosial bisa berkembang dan semakin besar bila ada dukungan lembaga yang mampu mengorganisir potensi-potensi para anggotanya.

Jalan yang diambil oleh para pengrajin gula kelapa Desa Ketanda dengan mendirikan pra-koperasi menjadi pilihan yang relevan. Tidak terlalu dini untuk merelevansikan koperasi sebagai lembaga yang tepat untuk mengembangkan modal sosial karena koperasi adalah lembaga yang mendefinisikan diri sebagai perkumpulan orang (people based association). Bila basis material korporasi sebagai lembaga perkumpulan modal (capital based association), maka koperasi memiliki fungsi pembagunan yang berpusat pada manusia. Dengan dasar ini, sudah menjadi fungsi inheren koperasi untuk mampu mengartikulasikan modal sosial lebih luas demi kepentingan dan kemajuan bersama (Faedlulloh, 2015).Di sisi lain, koperasi sebagai badan usaha ekonomi juga bersifat unik karena tanpa mereduksi prinsip ekonomi yang dipegang, koperasi harus mampu menjalankan fungsi sosialnnya. Dalam bidang ekonomi, koperasi berperan dalam meningkatkan pendapatan, menciptakan lapangan kerja, meningkatkan taraf hidup rakyat, dan memeratakan pendapatan (Sinuraya, 2012).

\section{KEPERCAYAAN ANTAR ANGGOTA}

Tindakan kolektif dalam menyelesaikan permasalahan yang terjadi dalam masyarakat desa tidak hadir begitu saja. Partisipasi serta kerjasama yang ada pada masyarakat timbul dalam kondisi modal sosial yang kuat (Kusumastuti, 2015). (Fukuyama, 2001) memaparkan bahwa saling percaya adalah elemen fundamental dari modal sosial. Bila pembangunan yang dicita-citakan ingin berhasil, maka harus dilandaskan pada rasa saling percaya. Pembangunan dan sikap saling percaya saling berkelindan, dan proses yang menyertainya selanjutnya mengakumulasi rasa saling percaya. Sikap saling percaya (trust) dari para anggota pengrajin kekuatan awal yang didorong tidak lagi menjadi kekuatan individu, tetapi kekuatan yang sosial. Kekuatan yang terakumulasi menjadi "senjata perlawanan". 
Rasa saling pecaya adalah energi kolektif masyarakat untuk mengatasi permasalahan bersama dan sumber motivasi untuk mencapai kemajuan ekonomi bersama (Hasbullah: 2006). Rasa saling percaya ini tumbuh dan berakar dari nilai-nilai yang melekat pada budaya kelompok. Sosiolog klasik, Durkhein (1973) menyebut energi kolektif masyarakat ini sebagai solidaritas organik atau para penganut aliran ekonomi baru menyebutnya sebagai solidaritas spontan.

Bergabungnya para pengrajin ke dalam organisasi merupakan satu bentuk jejaring keterlibatan masyarakat untuk meningkatkan rasa saling percaya. Erat kaitannya dengan ini, meminjam pemaparan Putnam (1993),keterlibatan dan partisipasi masyarakat, akan meningkatkan biaya potensial bagi pihak-pihak yang melakukan pelanggaran norma dalam setiap transaksi individual, menyuburkan resiprositas, memfasilitasi dalam komunikasi, memperbaiki arus informasi mengenai jejak rekam seseorang, dan mewujudkan sukses masa lampau dalam kerjasama yang dapat bermafaat sebagai contoh bagi kerjasama yang dijalin masa mendatang. Para anggota Argo Mulyo Jati bisa saling mengkontrol terhadap aktivitas organisasi sehingga organisasi bisa berjalan dengan baik. Hal ini hadir secara tegas ketika masa awal-awal pendirian embrio Argo Mulyo Jati. Saat itu para tengkulak sudah melakukan resistensi dengan cara menutup pasar produk-produk gula kelapa yang dibuat oleh para anggota Argo Mulyo Jati. Di awal-awal, para pengrajin yang menjadi anggota mulai menyetor gulanya di rumah salah satu pengrajin yang sudah disepakati bersama. Kemudian hasil dari kumpulan gula tersebut diambil oleh salah seorang distributor yang menjadi anggota Argo Mulyo Jati. Para tengkulak tidak bisa menerima hal ini karena tidak menerima jatah setoran gula seperti biasanya. Akhirnya sebagian dari anggota harus secara sembunyisembunyi ketika menyetor gula ke anggota distributor yang disepakati.

Para tengkulak bekerja seperti mafia kartel, mengkoordinasi dengan sesama tengkulak agar para calon pembeli jangan membeli produk hasil dari Koperasi Argo Mulyo Jati. Dengan kata lain mem-blacklist produk-produk Argo Mulyo Jati. Kondisi semakin kompleks karena masih ada para pengrajin yang terikat hutang dengan tengkulak sehingga memiliki bargaining position yang lemah. Maka dengan situasi ini, mau tidak mau para anggota harus menyadari tentang pentingnya kemandirian. Dengan difasilitasi Kopkun Institute, para anggota diajak berlatih dan tekun untuk menabung. Para anggota secara rutin menabung Rp.1000,/hari. Walau pada awalnya mengalami kesulitan dalam merubah kebiasaan, secara perlahan aktivitas menabung menjadi kebutuhan bagi para anggota. Hasil dari tabungan tersebut, secara perlahan dengan cara bergeliran dibuat untuk membayar hutang sebagain pengrajin kepada para tengkulak. Hal ini menunjukan bahwa para anggota kini mempunyai kesadaran penuh tentang pentingnya kemandirian. Tanpa adanya kepercayaan, program menabung ini sulit terjadi karena Argo Mulyo Jati bukan "lembaga kredit resmi". Dengan kata lain segala aktivitas bertopang pada rasa percaya tersebut. 
Konflik di awal pendirian Argo Mulyo Jati terjadi karena dinilai gerakan dari para anggota yang terlalu konfrontatif oleh para tengkulak. Ketika hutang menjadi masalah, para anggota sepakat priotitas pertama Argo Mulyo Jati adalah membayar semua hutang para anggota. Hal itulah yang sempat membuat para tengkulak di Desa Ketanda begitu reaksioner, terlebih saat itu ada Kopkun Institute sebagai lembaga eksternal yang dianggap mampu membantu finansial para pengrajin secara cepat. Padahal, pendekatan Kopkun Institute kepada Argo Mulyo Jati selama ini merupakan pendampingan secara organisasi serta pelembagaan nilai-nilai dan jatidiri koperasi. Reaksi yang dilakukan para tengkulak disebabkan karena adanya kekhawatiran bila para pengrajin langsung mampu membayar hutang-hutangnya, maka setoran gula kelapa kepada mereka bisa berkurang. Alhasil para tengkulak berkumpul untuk melakukan serangan balik dengan memberikanblack list sehingga menutup akses pasar bagi Argo Mulyo Jati.

Konflik tersebut seiring waktu semakin mereda, karena asumsi para tengkulak tidak sepenuhnya terjadi. Memang, ada proses mewujudkan kemandirian yang dilakukan para anggota Argo Mulyo Jati, akan tetapi semua itu terjadi secara evolusioner, mengingat kapasitas dan produksi yang masih terbatas. Sehingga para anggota, khususnya yang masih terikat dengan hutang, masih melakukan setoran gula kelapa kepada para tengkulak, sedangkan sisanya disetor kepada Argo Mulyo Jati yang saat ini pengelolaan sudah mandiri. Setidaknya apa yang telah dilakukan oleh para anggota Argo
Mulyo Jati dapat memutus rantai tengkulak (walaupun belum sempurna) dengan cara kolektif. Dengan memutus rantai, otomatis ada efisiensi dan berdampak pada keuntungan bersama yang didapatkan para anggota Argo Mulyo Jati.

Dinamika yang terjadi di kalangan pengrajin gula kelapa Argo Mulyo Jati mengkonfirmasi tesis dari Gambetta (2000) yang menyatakan berbagai tindakan kolektif yang didasari rasa saling percaya yang tinggi akan meningkatkan pasrtisipasi masyarakat dalam berbagai bentuk dan dimensi, terutama dalam konteks membangun kemajuan bersama.

\section{PELEMBAGAAN GOTONG ROYONG}

Proses pelembagaan adalah suatu proses yang dilewati oleh sesuatu norma atau nilai masyarakat yang baru untuk menjadi bagian dari salah satu pranata sosial. Pranata sosial dianggap sebagai peraturan apabila normanorma tersebut membatasi serta mengatur perilaku orang-orang di dalam lingkungan pranata itu berada(Soekanto, 1997).

Pada kajian ini, pelembagaan yang terjadi di Desa Ketenda bukanlah proses pelembagaan nilai yang bisa dikatakan benarbenar baru, karena sebenarnya konsep gotong royong sudah sangat akrab dalam kehidupan masyarakat Indonesia. Secara sederhana, gotong royong memiliki pengertian sebagai bentuk partisipasi aktif setiap individu untuk ikut terlibat dalam memberi nilai tambah atau positif kepada setiap obyek, permasalahan atau kebutuhan orang banyak di 
sekelilingnya. Implementasi nilai gotong royong dalam kehidupan masyarakat mengandung makna inheren berupa kesetaraan, keadilan, kebersamaan, kepedulian dan mengacu pada kepentingan bersama(Rochmadi, 2012).

Secara konseptual, gotong royong juga dapat dimaknai sebagai suatu model kerjasama yang disepakati bersama. Kerjasama merupakan bentuk konkret dari modal sosial. Kerjasama adalah jaringan suatu usaha bersama antara orang perorangan atau kelompok manusia untuk mencapai tujuan bersama. Hampir semua kelompok manusia dapat ditemui pola-pola kerjasamanya.

Proses pelembagaan kembali nilai gotong royong para pengrajin gula kelapa di Desa Ketanda terdapat peran dari Kopkun Institute sebagai lembaga yang terus mendampingi kegiatan usaha Agro Mulyo Jati. Dalam konteks ini, menurut penulis, Kopkun Institute berperan sebagai intelektual organik. Bagi Gramsci, intelektual organik merupakan para intelektual yang tidak hanya menjelaskan kehidupan sosial dari luar berdasarkan kaidah-kaidah saintifik, tapi juga memakai bahasa kebudayaan untuk mengekspresikan perasaan dan pengalaman riil yang tidak bisa diekspresikan oleh masyarakat sendiri (Kolakowski, 1978).

Langkah awal yang diselenggarakan Kopkun Institute adalah melakukan pemberdayaan masyarakat dan penguatan organisasi. Pemberdayaan itu sendiri merupakan proses yang mengupayakan peningkatan kemampuan pada individu dan/atau lembaga yang berada di dalam masyarakat untuk dapat memiliki kemandirian, yang kemudian memungkinkan lepas dari ketergantungan pada pihak lain (Harsono, 2014).

Kopkun Institute dan pengrajin gula kelapa Desa Ketanda melakukan beberapa kali analisis sosial-ekonomi untuk mengidentifikasi dan menemukan permasalahan dasar yang dihadapi pengrajin. Dari perhitungan yang dilakukan bersama terdapat temuan yang mencengangkan. Terdapat ketidakseimbangan antara pendapatan dan pengeluaran para pengrajin. Dalam setiap bulannya, rata-rata pengrajin selalu mengalami defisit sampai angka Rp.1000.000-an. Untuk menutup defisit tesebut tiada lain cara yang digunakan mereka adalah dengan meminjam/berhutang. Pihak yang sering dijadikan tempat meminjam yaitu bank ucek-ucek dan tengkulak. Tentunya dua pilihan tempat pinjaman ini, alih-alih mendapat manfaat, justru menuai dampak buruk bagi kehidupan rumah tangga para pengrajin. Bila meminjam ke bank ucek-ucek, maka konsekuensi yang harus diterima langsung oleh para pengrajin adalah bunga yang sampai $20 \%$. Hal ini begitu memeras para pengrajin. Sedangkan bila melakukan pinjaman kepada tengkulak, konsekuensi yang diterima oleh pengrajin akan memposisikan mereka selalu sub-ordinat dengan tengkulak. Mereka jadi terikat dengan satu juragan. Karena relasi hutang tersebut, tidak jarang produk gula kelapa para pengrajin dibeli lebih murah oleh tengkulak. Akibatnya, seperti lingkaran setan, mereka justru terjebak dengan hutang yang menumpuk.

Kondisi ini sudah terjadi bertahun-tahun lamanya di Desa Ketanda, oleh karenanya merupakanhal yang tidak mudah untuk 
merubahnya dalam tempo waktu yang cepat. Justru di titik inilah, menjadi kesempatan bagi Kopkun Institute memilih pengembangan kapasitas organisasi terlebih dulu bagi Argo Mulyo Jati, karena pada dasarnya para pengrajin sudah memiliki dan menjalankan usaha, namun sayangnya usaha tersebut belum bisa menjawab secara penuh kebutuhan mereka.

Proses pendampingan ini menjadi momentum sarana untuk kembali melembagakan nilai gotong royong dalam sendi kehidupan pengrajin gula kelapa di Desa Ketanda. Aktivitas usaha sebelumnya dikerjakan sendiri-diri, kini dikoordinasi dan diorganisasi sedemikian rupa untuk memperkuat posisi tawar mereka di tengah relasi yang timpang dengan para tengkulak.Walaupun tidak memutus langsung rantai dengan para tengkulak, tapi setidaknya posisi organisasi Argo Mulyo Jati kini lebih setara dengan para tengkulak. Kini hasil produksi para anggota Argo Mulyo Jati tidak wajib disetorkan kepada para tengkulak yang dulu harganya ditetapkan sepihak oleh tengkulak. Hasil produksi bisa disetorkan ke organisasi yang berperan menjadi "tengkulak kolektif" untuk menjualnya kepada pasar. Temuan menarik saat ini yaitu harga beli yang ditetapkan Argo Mulyo Jati terhadap hasil gula kelapa yang dibuat para petani di Desa Ketanda menjadi patokan bagi para tengkulak lainnya. Hal ini menjadi kemenangan kecil bagi para petani, walaupun tidak semua pengrajin gula kelapa Desa Ketanda menjadi anggota Argo Mulyo Jati, harga yang ditetapkan Argo Mulyo Jati dinilai lebih wajar. Situasi ini tentu bisa tercipta karena para anggota Argo Mulyo Jati adalah para pengrajin dan petani gula kelapa itu sendiri yang memahami kondisi riil. Jadi ada ruang emansipasi yang dimanfaatkan para petani untuk menentukan harga yang ditawarkan secara wajar dan fair.

Saat proses pendampingan, para pengrajin dikenalkan dengan nilai-nilai dan prinsip koperasi. Secara perlahan, nilai dan prinsip diinteralisasi dalam setiap aktivitas usaha produksi gula kelapa. Selain nilai dan prinsip koperasi, para pengrajin juga diberikan pendidikan pengantar tentang pengelolaan keuangan yang langsung diaplikasikan dalam kegiatan usaha mereka. Jadi saat ini tata kelola keuangan, akuntansi, sampai pembukuan organisasi berjalan jauh lebih baik.

Pendampingan adalah tentang komitmen nilai. Hal ini yang berlaku antara Argo Mulyo Jati dan Kopkun Institute, dua lembaga ini saling bekerjasama, saling memberikan rasa percaya. Kopkun Institute percaya Argo Mulyo Jati bisa berkembang, begitu pula sebaliknya Argo Mulyo Jati percaya kepada Kopkun Institute akan memberikan pendampingan secara serius. Prasyarat saling percaya ini menjadi hal yang utama, karena mobilisasi sekuat apapun bila tidak diawali dengan saling percaya akan menjadi kerjasama yang kontra-produktif.

Adapun aktivitas pendampingan Kopkun Institute dalam bentuk pemberian edukasi yaitu dengan caraberdiskusi langsung dengan para anggota yang diselenggarakan di Desa Ketanda. Selain pemberian materi dalam bentuk kelas yang diselenggarakan di Kantor Kopkun Institute,tidak jarang untuk menemukan jawaban bersama terkait permasalahan, pegiat Kopkun Institute 
melakukan live in bersama warga untuk mempelajari dan melakukan analisa sosial (ansos) permasalahan yang ada di Desa Ketanda.

Selama proses edukasi ini, ada hal menarik yang bisa dipelajari, yaknisaat kegiatan pemberian materi dalam bentuk kelas yang dilaksanakan di Kantor Kopkun Institute. Berarti para anggota Argo Mulyo Jati harus menempuh jarak sekitar 38 kmdari Desa Ketanda ke Purwokerto untuk mengikuti kelas. Mereka berbondongbondong naik mobil pick up.Tidak sedikit ibuibu yang ikut serta dalam kelas yang biasa diselenggarakan pada malam hari (setelah isya) dan berahir sampai tengah malam. Keadaan ini menjadi pemandangan yang menarik, semangat yang ditunjukan para anggota untuk belajar sangat luar biasa. Pastisipasi aktif yang ditunjukan oleh para anggota Argo Mulyo Jati, seperti yang dijelaskan Mikkelsen(Susiana, 2000), menjadi alat untuk mengembangkan diri sekaligus tujuan akhir. Mereka mau belajar hal-hal baru untuk mengembangkan diri mereka sekaligus untuk membantu mencapai tujuan organisasi.

Partisipasi yang melibatkan emosi dan mental akan menimbulkan rasa harga diri dan kemampuan pribadi untuk dapat turut serta dalam keputusan penting yang menyangkut masyarakat banyak. Ketika para anggota menyatakan pendapatnya langsung dalam membuat keputusan organisasi, itulah imbas dari partisipasi yang menghasilkan pemberdayaan. Dalam jaringan sosial, partisipasi memegang peranan yang cukup penting, karena kerjasama yang ada dalam komunitas dapat terjadi karena adanya partisipasi individu-individu. Begitupula dinamika yang terjadi di anggota Argo Mulyo Jati, partisipasi mereka mampu menghasilkan rasa percaya diri dan mengembangkan kemampuan mereka dalam berorganisasi.

Bermula dari beberapa orang, saat ini sudah ada 60 orang yang menjadi anggota Argo Mulyo Jati. Hal ini dampak posisitif imbas dari kepercayaan para pengrajin terhadap organisasi tersebut.Saat ini unit usaha Argo Mulyo Jati mulai berkembang, selain produksi gula kelapa, mereka melakukan diversifikasi usaha dengan mendirikan warung sembako. Pendirian warung sembako ini "berhasil" mempekerjakan dua pemuda desa. Hal ini imbas positif yang langsung dirasakan oleh anggota Argo Mulyo Jati khususnya, dan warga Desa Ketanda pada umumnya.

Berkenaan dengan modal sosial, maka dinamika pelembagaan gotong royong yang berjalan selama ini yaitu diarahkan untuk menata kembali modal sosial terikat (bonding). Modal sosial bonding yaitu modal sosial antara individu dalam sebuah kelompok dengan melihat orientasi ke dalam (Kusumastuti, 2015). Kerjasama dan partisipasi yang tampak dalam kehidupan warga tidak hadir begitu saja, aktivitas tersebut adalah hasil dari semakin menguatnya modal sosial. Kerjasama dan partisipasi berjalan dinamis menyesuaikan dengan modal sosial bonding yang hadir dalam kehidupan anggota Argo Mulyo Jati.

Ketika modal sosial telah menjadi kekuatan dalam mengembangkan kapasitas organisasi, maka kapasitas tersebut bisa diarahkan untuk mengembangkan modal sosial yang berbentuk bridging atau modal sosial yang berorientasi ke luar. Modal sosial 
berbentuk bridging ini mengarah kepada pencarian jawaban bersama untuk menyelesaikan masalah yang dihadapi oleh kelompok dengan memanfaatkan jaringan yang dimiliki individu dalam kelompok. Modal sosial bentuk ini diasumsikan bisa mempertinggi kontribusi bagi perkembangan pembangunan dengan melakukan kontak dan interaksi dengan kelompok di luarnya (Kusumastuti, 2015). Hal ini sebenarnya sudah dilakukan oleh para pengrajin sendiri, karena kehadiran Kopkun Institute membantu mendampingi Argo Mulyo Jati ini tiada lain adalah imbas dari jaringan salah satu anggota Argo Mulyo Jati yang memperkenalkan mereka dengan Kopkun Institute. Keberadaan Kopkun Institute sendiri merupakan bentuk dari linking social capital yang berfungsi untuk menjalin hubungan atau jaringan sosial, baik kepada anggota masyrakat sendiri maupun terhadap pemerintah dan jejering kerja lainnya(Rijal \& Noer, 2013). Guna semakin memperkuat modal sosial bridging, dari "pertemuan" dua lembaga ini kemudian terbuka juga jaringan yang lain. Dalam catatan penulis saat ini Argo Mulyo Jati bertemu dengan jaringan-jaringan baru dengan lembaga-lembaga yang memberi daya dukung seperti Disperindagkop Banyumas, Kadin Banyumas, dan Dekopinda Banyumas, dan koperasi-koperasi lainnya. Lembagalembaga eksternal ini memiliki potensinya masing-masing bagi perkembangan Argo Mulyo Jati.

Sebagai lembaga yang mendampingi, Kopkun Institute menilai sebenarnya segala aktivitas gotong royong dan capaian yang terlah ditempuh selama inioleh Argo Mulyo Jati adalah hasil kerja mereka sendiri. Pada dasarnya, individu-individu di Argo Mulyo Jati sudah memiliki modal sosial, misal rasa saling percaya yang baik, namun belum dikonversi menjadi kekuatan bersama dalam bentuk organisasi. Dalam konteks ini, Kopkun Institute menjalankan peran untuk mendorong kepercayaan diri, pemberian soft skill, serta memberdayakan para pengrajin yang diarahkan pada kemandirian pengrajin.

\section{KESIMPULAN}

Di tengah kondisi para pengrajin gula kelapa yang masih jauh dari sejahtera, sebagian warga Desa Ketanda, Banyumas yang berprofesi sebagai pengrajin gula kelapa berinsiasif bergorganisasi mendirikan Argo Mulyo Jati. Organisasi ini bertujuan untuk meningkatkan kualitas hidup dan meningkatkan posisi tawar para pengrajin di tengah relasi sosial yang timpang. Modal sosial yang dimiliki warga dalam bentuk rasa saling percayamenjadi daya dukung dan kekuatan dalam aktivitas organisasi. Aktivitas usaha yang awalnya dilakukan sendiri-sendiri kini dilakukan dengan bekerjasama.

Modal sosial semakin berkembang dengan praktik pelembagaan nilai gotong royong yang dilakukan para pengrajin sehingga meningkatkan kapasitas organisasi. Praktik pelembagaan gotong royong ini didampingi Kopkun Institute. Para pengrajin dikenalkan dengan nilai-nilai dan prinsip koperasi. Secara perlahan, nilai dan prinsip diinteralisasi dalam setiap aktivitas usaha produksi gula kelapa. Para pengrajin juga diberikan pendidikan pengantar tentang pengelolaan keuangan yang langsung 
diaplikasikan dalam kegiatan usaha Argo Mulyo Jati.

Pengalaman dari Argo Mulyo Jati membuktikan kerja kolektif bisa memperbaiki kualitas hidup dan memperkuat posisi tawar di antara stakeholder gula kelapa di Desa Ketanda. Kerja kolektif ditransformasikan dalam mengorganisir dan memobilisasi segala sumber daya yang dimiliki para anggota sehingga tercipta kekuatan baru. Apa yang dilakukan para anggota Argo Mulyo Jati adalah proses, belum tuntas, dan perjalanan perjuangan masih sangat panjang. Namun selama modal sosial masih bisa terawat, kemungkinan organisasi untuk semakin berkembang dan semakin kuat tidaklah mustahil.

\section{DAFTAR PUSTAKA}

Arianto, K., \& Fitriana, E. N. (2013). Modal Sosial dalam Kemandirian Masyarakat d Bidang Kesehatan. Jurnal Kebijakan \& Administrasi Publik, 17(2), 37-49.

Berutu, L. (2005). Gotong Royong, Musyawarah dan Mufakat sebagai Faktor Penunjang Kerekatan Berbangsa dan Bernegara. Jurnal Antropologi Sosial Budaya Etnovisi, 1(1), 21-24.

Bourdieu, P. (1986). The Form of Capital. In J. Richardson (Ed.), Handbook of Theory and Research for Sociology of Education. New York: Greenwood Press.

Collette, N. (1987). Kebudayaan dan Pembangunan Sebuah Pendekatan Terhadap Antropologi Terapan di Indonesia. Jakarta: Yayasan Obor Indonesia.

Durkhein, E. (1973). Moral Education: Study in the Theory and Application of the Sociology of
Education. New York: Free Press.

Faedlulloh, D. (2015). Modal Sosial dalam

Gerakan Koperasi. The Indonesian Journal of Public Administration, 1(1), 1-20.

Fukuyama, F. (2001). Sosial Capital: Civil Society and Development. Third World Quarterly, 22.

Fukuyama, F. (2002). Trust: Kebijakan Sosial dan

Penciptaan Kemakmuran. Yogyakarta: Penerbit Kalam.

Gambetta, D. (2000). Trust: Making and Breaking Cooperative Relations. Oxford: Oxford: Department Sociology, University of Oxford.

Harsono, W. (2014). Jimpitan, Modal Sosial yang Menjadi Solusi Permasalahan Masyarakat. Jurnal Kebijakan $\mathcal{E}$ Administrasi Publik, 18(2), 131-146.

Jaetulloh, A. (2015). Ekonomi Politik Pengembangan Koperasi Serba Usaha (KSU) Nira Satria di Kabupaten Banyumas. Purwokerto: Universitas Jenderal Soedirman.

Kolakowski, L. (1978). Main Current of Marxism Vol III. Oxford: Clarendom Press.

Kusumastuti, A. (2015). Modal Sosial dan Mekanisme Adaptasi Masyarakat Pedesaan dalam Pengelolaan dan Pembangunan Insfrastruktur. MASYARAKAT: Jurnal Sosiologi, 20(1), 8197.

Moleong, L. J. (2004). Metode Penelitian Kualitatif. Bandung: PT. Remaja Rosdakarya.

Nazir, M. (2009). Metode Penelitian. Jakarta: Ghalia Indonesia.

Purwanto, A. (2013). Modal Budaya dan Modal Sosial dalam Industri Seni 
Kerajinan Keramik. MASYARAKAT: Jurnal Sosiologi, 18(2), 233-261.

Putnam, R. . (1993). Making Democracy Work:

Civic Traditions in Modern Italy. Princeton: Princeton University Press.

Putnam, R. . (2000). Bowling Alone. The Collapse and Revival of American Community. New York: Simon and Schuster.

Rijal, M., \& Noer, S. (2013). Peran Modal Sosial dalam Pelestarian Hutan. Jurnal Kebijakan E Administrasi Publik, 17(2), 20 36.

Rochmadi, N. (2012). Menjadikan Nilai Budaya Gotong-Royong Sebagai Common Identity dalam Kehidupan Bertetangga Negara-Negara ASEAN. Malang: Repository Perpustakaan Universitas Negeri Malang.

Sidik, F. (2015). Menggali Potensi Lokal Mewujudkan Kemandirian Desa. Jurnal Kebijakan \& Administrasi Publik, 19(2), 115131.

Sinuraya, R. E. (2012). Dialog Antar PrinsipPrinsip dan Nilai-Nilai Koperasi dengan Modal Sosial di Koperasi Kredit Marsudi Mulyo, Putat Patuk Gunung Kidul. Jurnal Kebijakan \& Administrasi Publik, 16(1), 7388.

Soekanto, S. (1997). Sosiologi Suatu Pengantar. Jakarta: Rajawali Press.

Susiana, S. (Ed.). (2000). Pembangunan Sosial, Teori dan Implikasi Kebijakan. Jakarta: Pusat Pengkajian dan Pelayanan Informasi Sekretariat Jenderal DPR RI.

Widayani, R., \& Rachman, N. A. (2013). Studi Tentang Kemunculan Modal Sosial. Jurnal Kebijakan \& Administrasi Publik, 17(2), 6575.

www.swa.co.id. (2016). Gula Kelapa RI
Tembus Pasar Dunia. Retrieved June 28, 2016, from http:/ / swa.co.id/swa/profile/entrepren eur/gula-kelapa-ri-tembus-pasar-dunia 